\title{
EARLY LANGUAGE LEARNING IN SCHOOL CONTEXTS
}

\section{Series Editor: Janet Enever, Umeå University, Sweden}

The early learning of languages in instructed contexts has become an increasingly common global phenomenon during the past 30 years, yet there remains much work to be done to establish the field as a distinctive area for interdisciplinary investigation. This international research series covers children learning second, foreign and additional languages in educational contexts between the ages of approximately 3 and 12 years. The series will take a global perspective and encourage the sharing of theoretical discussion and empirical evidence on transnational issues. It will provide a platform to address questions raised by teachers, teacher educators, and policy makers who are seeking understanding of theoretical issues and empirical evidence with which to underpin policy development, implementation and classroom procedures for this young age group. Themes of particular interest for the series include: teacher models and teacher development, models of early language learning, policy implementation, motivation, approaches to teaching and learning, language progress and outcomes, assessment, intercultural learning, sustainability in provision, comparative and transnational perspectives, cross-phase transfer issues, curriculum integration - additional suggestions for themes are also most welcome.

All books in this series are externally peer-reviewed.

Full details of all the books in this series and of all our other publications can be found on http://www.multilingual-matters.com, or by writing to Multilingual Matters, St Nicholas House, 31-34 High Street, Bristol BS1 2AW, UK. 


\section{Assessment for Learning in Primary Language Learning and Teaching}

\section{Maria Britton}


https://doi.org/10.21832/BRITTO0640

Library of Congress Cataloging in Publication Data

A catalog record for this book is available from the Library of Congress.

Names: Britton, Maria, 1983- author.

Title: Assessment for Learning in Primary Language Learning and Teaching/ Maria Britton.

Description: Bristol, UK; Blue Ridge Summit, PA: Multilingual Matters, 2021. Series: Early Language Learning in School Contexts: 5 | Includes bibliographical references and index. | Summary: "This volume provides a detailed account of the practical use of Assessment for Learning (AfL) in primary language classrooms. It gives an in-depth account of the ways in which eight experienced primary language teachers incorporated this type of assessment into their practice and discusses the possible impact of AfL on primary language learning"-Provided by publisher.

Identifiers: LCCN 2020052588 (print) | LCCN 2020052589 (ebook) | ISBN 9781800410633 (paperback) | ISBN 9781800410640 (hardback) | ISBN 9781800410657 (pdf) | ISBN 9781800410664 (epub) | ISBN 9781800410671

(kindle edition) Subjects: LCSH: Language arts (Primary)—Evaluation.

Classification: LCC LB1528 .B69 2021 (print) | LCC LB1528 (ebook) |

DDC 372.6—dc23 LC record available at https://lccn.loc.gov/2020052588

LC ebook record available at https://lccn.loc.gov/2020052589

British Library Cataloguing in Publication Data

A catalogue entry for this book is available from the British Library.

ISBN-13: 978-1-80041-064-0 (hbk)

ISBN-13: 978-1-80041-063-3 (pbk)

\section{Multilingual Matters}

UK: St Nicholas House, 31-34 High Street, Bristol BS1 2AW, UK.

USA: NBN, Blue Ridge Summit, PA, USA.

Website: www.multilingual-matters.com

Twitter: Multi_Ling_Mat

Facebook: https://www.facebook.com/multilingualmatters

Blog: www.channelviewpublications.wordpress.com

Copyright (C) 2021 Maria Britton.

All rights reserved. No part of this work may be reproduced in any form or by any means without permission in writing from the publisher.

The policy of Multilingual Matters/Channel View Publications is to use papers that are natural, renewable and recyclable products, made from wood grown in sustainable forests. In the manufacturing process of our books, and to further support our policy, preference is given to printers that have FSC and PEFC Chain of Custody certification. The FSC and/or PEFC logos will appear on those books where full certification has been granted to the printer concerned.

Typeset by Deanta Global Publishing Services, Chennai, India Printed and bound in the UK by the CPI Books Group Ltd. Printed and bound in the US by NBN. 